\title{
From Fear to Anxiety: An Exploration into a New Socio-Political Temporality
}

\author{
Andreja Zevnik ${ }^{1}$
}

Published online: 15 September 2017

(C) The Author(s) 2017. This article is an open access publication

\begin{abstract}
Modern political reality is increasingly permeated with testimonies and representations of social and personal anxieties. Most often these narratives are accompanied with a desire to identify and implement a 'cure' that will either heal or eradicate the source of discomfort. In the political everyday such a 'cure' is disguised as a policy or a new law. Thus it comes as a little surprise that the term anxiety is increasingly used by politicians, policy-makers, legal and medical experts as well as scholars to explain an allegedly new social phenomenon. Relying on psychoanalysis and critical theory the contributions in this special issue tackle modern anxieties in the realms of politics and law, and in particular look into how anxiety is manifested in relation to resistance, immigration, nationalism and austerity measures. This introduction firstly, unpacks the idea of anxiety conceptually and offers different ways in which anxiety can be read politically, legally as well as theoretically; and secondly introduces the arguments put forward in individual contributions.
\end{abstract}

Keywords Anxiety · Psychoanalysis · Jacques Lacan · Socio-political order $\cdot$ Modernity $\cdot$ Identity

Modern political reality is increasingly permeated with testimonies and representations of social and personal anxieties. Most often these narratives are accompanied

This special issue originates in the discussions we had at a workshop organised in the Politics department at the University of Manchester in 2015 by Andreja Zevnik and Aoileann Ni Mhurchu. Since then we had on-going discussions on the role of anxiety in the modern socio-political sphere, which also drew in new contributors. The presented issue is a testimony to the discussions we have had.

Andreja Zevnik

andreja.zevnik@manchester.ac.uk

1 Department of Politics, School of Social Sciences, University of Manchester, Oxford Road, Manchester M13 9PL, UK 
with a desire to identify and implement a 'cure' that will either heal or eradicate the source of discomfort. In the political everyday such a 'cure' is disguised as a policy or a new law. Thus it comes as a little surprise that the term anxiety is increasingly used by politicians, policy-makers, legal and medical experts as well as scholars to explain an allegedly new social phenomenon. In the realm of security, for example, anxiety seems to denote a particular unexplainable or unpredictable emergence of a threat or its unexpected consequences. In domestic politics, most recently, the elections around the Western world triggered anxieties of political elites prompting them to ask but 'What do the people want? Who will they choose to lead them this time?' while psephologists more anxiously than ever await the accuracy of their polling projections. In the personal realm, anxiety often describes an experience of unease or uncertainty about one's future or inability to cope with everyday social and work pressures. These personal and societal discourses have something in common. First, there is a somewhat peculiar discursive move at play by which anxiety, it seems, replaced fear. If fear or the experience of fear is something comprehensible, identifiable and in turn (possibly) easily removable from or manageable in everyday social and political realities, anxiety, in contrast, suggests the experience of something that is more porous, liquid, unidentifiable, unknown and perhaps even absent. Second, the dominance of anxiety over fear is reflected in a move from the known and manageable to that which is unknown and requires new managerial strategies. Thirdly, and not unrelated, this, as Ulrich Beck (1992) and Anthony Giddens (1991, 2013) argue, holds implications and is directly reflected in our relationship to knowledge.

Giddens (1991) and Beck (1992) speak about risk society as a distinct practice of social order and governance. This is a society where fear is a predominant feature of social unease. For Giddens and Beck, it is in the risk society that the expert and scientific knowledge take over the social field. It responds as well as creates a desire for quantifying social conditions-from an individual's everyday life-style to community actions, state behaviour, and risks imposed by external phenomena such as natural disasters. By knowing the risk, an individual or a community could make informed choices, which should control if not eliminate danger. Such decisions transformed political communities and their everyday life, with 'rational choice' triumphing in this exercise. Thus, 'risk society' became the answer to individual and societal fears but, with its desire to quantify and assess, it produced fear of things that are commonly not regarded as threats. Despite aiming at governing practices of a state or a community, the logic of risk spilt over into citizens' intimate and private spheres and, perhaps more than ever before, it introduced the calculative into everyday life (just think of the number of apps monitoring one's health and promoting an active lifestyle). With its focus on 'what one knows', risk society is a driver of the status quo. On the one hand, risk society is comforting and reassuring while, on the other hand, any political change becomes categorised as risk to the maintenance of the status quo.

If risk society sought the elimination of fear, it also generated fear as risks were identified but not neutralised. A more recent move from fear to anxiety concerns precisely the persistence of fear and the realisation that at no point can one eliminate all risk, neutralise all fear or perfectly immunise society. The logics of neutralisation 
first and immunisation second came hand in hand, I argue, with a move from the logic of fear to the logic of anxiety (Eklundh et al. 2017). Moreover, as Žižek (1992) might suggest, the move to anxiety denotes precisely the realisation that a complete elimination of fear or risk is a social fantasy, a narrative, which provides reassurance and, in turn, creates and maintains social cohesion and order. The dominance of anxiety, however, does not do away with fear. The contributions in this special issue will show how fear becomes a way of easing anxiety; of attaching a signifier (an object of fear) to what is otherwise an unfounded experience of unease and how the trajectory between fear and anxiety changes political temporality.

The above is only a snapshot of the field of the contributions to this special issue entitled From Fear to Anxiety: An exploration into a new socio-political temporality. In particular the contributions look at the socio-political changes produced by a move from fear to anxiety. They place the significance of the logic of anxiety on the way anxiety operates and orders the socio-political realm, and the impact that anxiety has on individuals' everyday life. In the realm of political action, for example, socio-political anxiety can paralyse the subject by exposing it to great, unknown, unpredictable dangers, which in turn make the subject more prone to guidance and control. Joanna Bourke (2006), for example, speaks of anxiety as a form of anaesthesia that penetrates into all pores of social and political life, with an aim of displacing time. It fixates the existence of the subject in the present moment, while dismantling any dreams or illusions of a different/better future. In contrast, anxiety can also mobilise and support political action-in the moment when the subject is faced with the realisation that the sovereign does not know (is impotent and cannot provide the security), the subject begins to question its own relation to sovereign authority (Zevnik 2017; Žižek 1992). In those moments anxiety becomes a productive force, which can lead to action. It can disguise itself as a revolutionary force, although, as Jacques Lacan (2007) would say, one should not get too excited about the revolutionary spirit as it often leads to a re-institution of the same kind of power that revolutions fight to undermine. And perhaps this warning is exactly what Søren Kierkegaard (2015) had in mind in his work on anxiety when he first linked anxiety to the experience of transgression of some unwritten rule, or (rather pertinent today) when he spoke about the 'populist anxiety' and the unease of giving people too much power in political decisionmaking. As discussions later on will show, actions enticed by anxiety can derive from the entire political spectrum, from those on the radical right to others on the radical left and in-between. In fact (as Hirvonen's contribution shows), the right has often a bigger claim in mobilising racial anxieties, with populism (as McDonald's contribution demonstrates) at its centre.

Anxiety, anguish, and fear are terms not uncommon in the history of political philosophy. Yet, often these terms are misused or applied in a rather fashionable manner. While the papers in this special issue draw their inspirations from a number of authors, and create their own theoretical frameworks, this introduction elaborates on Jacques Lacan's writing on anxiety, primarily, to illustrate what is at stake when one speaks about anxiety; and, secondly, to further highlight the socio-political implications that individual contributions in this special issue make. Lacan's theory of anxiety is brought into a socio-political realm where the experience of anxiety 
underlies the function and the structure of the subject as well as the discourse, its relation to authority and to meaning-production. The remainder of this introduction will elaborate on the socio-political dimensions of anxiety before briefly introducing individual contributions.

\section{The Place of Anxiety}

Locating anxiety is a difficult task because, if anything, anxiety is marked by absence more than by presence. Kierkegaard (2015) wrote about anxiety as a possibility which emerges with breaking the unwritten rule or Law. It is not the transgression which causes anxiety but the possibility, the temptation to do so. The significance of Kierkegaard's observation is well explained by Žižek who writes:

So when, in a move described by Kierkegaard, one withdraws from the dizziness of freedom by seeking a firm support in the order of finitude, this withdrawal itself is the true Fall. More precisely, this withdrawal is the very withdrawal into the constraints of the externally-imposed prohibitory Law, so that the freedom which then arises is the freedom to violate the Law, the freedom caught into the vicious cycle of Law and its transgression, where Law engenders the desire to 'free oneself' by way of violating it, and 'sin' is the temptation inherent to the Law - the ambiguity of attraction and repulsion which characterizes anxiety is now exerted not directly by freedom but by sin. (Žižek 2005)

The subject begins to obey the law not because it thinks it is good, but because it fears transgression, it fears what might happen if it is to pursue its desire. For Kierkegaard (2015) and for Lacan (2014), the place from which anxiety emanates here is not the prohibition but the subject's willful subordination to law, and crucially the guilt which the subject experiences not from breaking the law but from NOT breaking it; the guilt of giving up on one's desire. Or, as Žižek (2005) writes:

we obey the Law, we do it as part of a desperate strategy to fight against our desire to transgress it, so the more rigorously we OBEY the Law, the more we bear witness to the fact that, deep in ourselves, we feel the pressure of the desire to indulge in $\sin$. [...T] he more we obey the Law, the more we are guilty, because this obedience effectively IS a defense against our sinful desire.

Lacan (2014) took this cue precisely from Kierkegaard and placed transgression or illusion of freedom at the centre of anxiety. As both Lacan and Kierkegaard suggest, anxiety emerges from a particular place internal to 'subject formation' (that is, the way in which an individual becomes a political subject). The place from which anxiety emanates, following Lacan (2014, pp. 16-28), is the gap or the relation between the subject and the authority (sovereign/Law), the relation through which the subject comprehends and makes sense of the social world. Because of this ambiguous relation to/with the Other, anxiety is different from fear. For Freud, who perhaps pioneered the study of fear and anxiety, fear has an object, whereas anxiety 
comes with no object. In A General Introduction to Psychoanalysis (1920) Freud describes the relationship between fear and anxiety in the following way:

I think that anxiety is used in connection with a condition regardless of any objective, while fear is essentially directed toward an object. Fright, on the other hand, seems really to possess a special meaning, which emphasizes the effects of a danger which is precipitated without any expectance or readiness of fear. Thus we might say that anxiety protects man from fright. (Freud 1920)

Instead of being afraid of what one can name or point to, for Freud (1920), anxiety evokes a particular feeling of unease, which cannot be explained or caught in knowledge. It can even be a primordial and pre-social reaction of the body that is beyond the subject's conscious control. While such a distinction between fear and anxiety is too vague and for the analysis of the modern socio-political reality also incomplete, Lacan shows why Freud's thought is not obsolete. In re-examining Freud's work Lacan elaborated on the difference between fear and anxiety by introducing one crucial element. He said that a reaction to anxiety hints towards the existence of something more fundamental; it hints to the presence of a particular structure, which, through its split produces an anxious subject (Lacan 2006, pp. 671-702; 2014, pp. 3-15). The structure Lacan has in mind here is precisely one which turns an individual into a political subject. It is a structure which, as said earlier, puts the subject in relation to the place of authority, but it is also a structure which turns an individual into a subject by preventing the subject from limitless enjoyment or obtaining the object of its desire. In as much as this is the birth of the famous 'lacking subject' and it is also a birth of an anxious subject.

Lacan named the object which triggers anxiety surplus jouissance or object petit $a$. He writes: 'I say on the contrary that anxiety is not without an object. [... The object of anxiety] is not a name. It's surplus jouissance, but it's not nameable, even if it is approximately nameable, translatable, in this way' (2007, pp. 147). What is implied in Lacan's statement is that anxiety does have an object; in psychoanalytic thought this is not just any kind of object but an object par excellence. It is the most significant object as it marks a place of absence. It is that which drives the desire; it is that which attaches the subject to a master signifier (a sovereign, a source of authority); and it is that for which the subject seeks fulfilment through fantasies or objects of desire. Object petit $a$ is fundamental if one is to think of a split, postmodern subject (or the subject of psychoanalysis) and its socio-political action.

Lacan's theory of the 'Graph of Desire' most directly addresses the significance of anxiety and the 'defence'-fantasies-mechanisms the subject develops against it. In the 'Subversion of the Subject and the Dialectics of Desire' Lacan (2006, pp. 671-702) explains how an individual becomes subjectivised into the symbolic order. In other words, how the individual internalises the authority of the sovereign and learns to desire in a socially acceptable way. Such inclusion into the symbolic order, however, comes at an expense; the prime casualty of such an inclusion is enjoyment. By subjugating oneself to the symbolic order, the subject no longer has access to the absolute surplus jouissance (that is enjoyment which is socially destructive). But as with every prohibition, the prohibition of jouissance is not complete. A trace of that absolute jouissance is retained in the place of object petit a 
and, in turn, of anxiety. Commonly the relationship between the subject and its object petit $a$ is mediated through the construction of social fantasies (Lacan 2014, pp. 3-6). Social fantasy is an imaginary narrative that the subject produces, and concerns reasons for why something cannot be attained, or what comes as a tradeoff for the 'castration'. ' When the subject is fully identified with the symbolic order, it knows what its role and social mandate is. In other words, it knows what it is supposed to do, and what its relation to the sovereign is. The subject knows what it needs to give and what it will receive. For example, the fantasy of state security leading to individual security is one such narrative.

The subject in turn also locates and places the objects of fear into the place of object petit $a$. Those objects (figures) of fear are commonly those that the sovereign discourse identifies as destructive to the community and its social cohesion and hostile to that which one holds as their identity. In the moment when the subject is placing outsiders into the place of object petit $a$, two important things take place. The subject assumes that these figures (the migrant, the foreigner, the black, the Muslim) have access to that which the subject sacrificed in order for it to become a member of the symbolic order (a community). The subject assumes the 'outsider' has access to surplus jouissance; the jouissance that the subject traded for its inclusion into the symbolic order and which the subject has still never really given up on entirely. ${ }^{2}$ These figures also occupy a place which should remain empty. Lacan (2014, p. 41) in his seminar On Anxiety says that anxiety appears when lack in no longer lacking. That is precisely where an object (of fear) suddenly occupies that lack. The proximity of that object stirs a subject's feelings, and mobilises it to take action. Often that comes in the form of radical right-wing fantasies and political projects that are driven by the exclusion of whatever it is that is different from us. Hirovonen's contribution to this volume elaborates precisely on the racist narratives that develop from the moment when the racial other occupies the place of object petit $a$; while Barnard-Naudé's contribution (in part) explores what happens when that very same place is occupied by the idea of a revolution.

When the outsider occupies the space of object petit $a$ the bond between the subject and the sovereign commonly strengthens; however, the relationship between the subject and its sovereign can also be disturbed by the presence of something in the place of the object petit $a$. Whatever it may be that disrupts the relationship, in that moment the subject realises that the sovereign also does not know, and realises that the sovereign cannot provide the security for which the subject sacrificed its desire, and that the role the subject is to play in the social field is ambiguous. At that moment the subject voices the famous 'Che vuoi?' in the direction of the sovereign. 'But what do you want from me?' (Lacan 2014, p. 6). This question pierces into the sovereign's authority because the subject subjugated itself to the sovereign on the assumption that the sovereign knows what the subject should do. On the assumption that the sovereign knows, the subject follows the sovereign. Moreover, the subject

\footnotetext{
1 With the 'trade-off for castration' I mean subjects' sacrifice of their experience of the absolute jouissance for their inclusion into a symbolic order.

${ }^{2}$ This is also a point made by Kierkegaard-the subject experiences anxiety or sins because while it obeys the law, the subject feels guilty because it is betraying its desire to transgress it.
} 
begins acting in the way in which it thinks is required by the sovereign; it wants to appear in an image it thinks the sovereign wants them to appear (Lacan 2014, pp. 23-28). By questioning the authority the subject's role in the social field is reopened. The appeal the sovereign had is gone. Lacan (2007) would often associate this moment with the hysteric and their rejection of sovereign authority.

By questioning the sovereign's authority the symbolic order collapses and the subject is exposed to anxiety. A reaction to what is now a lack of authority or structure can materialise in action. Barnard-Naudé in his contribution described this action as either 'acting out' or a passage à l'acte. The two strategies of resistance to sovereign authority come at the back of the experience of anxiety, which push the subject to make an ultimate shift in its symbolic order. That is, the subject has come to realise how porous sovereign authority is and wishes to call it into question. In the acting out, the subject performs a hysteric move of opposition to sovereign authority (Bosteels 2006; Lacan 2007; Zevnik 2009). Such a performance of opposition to the sovereign can derail the symbolic order, but in effect it ultimately re-institutes the sovereign in the same or in a somewhat different form. It is this act that Lacan in 1968 in his talk to the students at Vincennes (1977) described as 'resist, but all you will get is a new master'. Perhaps in a somewhat pessimistic way, this is exactly what happened in Greece: first hope and then the dissolution of hope that came with the election of Syriza into power (the effects of this dissolution are well addressed here in Loizidou's contribution).

By contrast, passage à l'acte does away with the symbolic order. It is a moment when the subject escapes the symbolic network; it is dissolution of the social bond as Žižek (1992) explains. In effect this is also a symbolic death of the subject, its refusal to participate in the network of symbolic power relations and in the reinstatement of sovereign authority. In this move, however, the 'usefulness' of the subject's actions can always be questioned: are the subject's actions a 'simple' refusal of sovereign authority, the institution of a different symbolic order or something entirely new (the emergence of a new world)? It is difficult to determine what will emerge from passage à l'acte. If it is the emergence of a new world, then one lacks a discourse to describe it as it emerges at the borders of what Lacan would call the traversal of the fantasy (that is, a disappearance of one fantasy, a possible emergence of another and/or a defence/refusal of any fantasy). A possibility of such a world is briefly discussed at the end of Hirvonen's piece. If anxiety is addressed through a refusal, then perhaps what one witnesses is closer to Roger's discussion of the law in the context of postcolonial Australia. In Roger's paper the refusal, however, does not derive from the subject/the citizen of Australia but from the Indigenous who, through their refusal to participate or acknowledge the law of the land (that is Australia), trigger anxiety not in the Indigenous but in non-Indigenous Australians. The Indigenous is not concerned by the way in which they will be perceived in the eyes of the law. The Australians (as citizens), however, are faced with the refusal/denial to have their 'desire' (and in turn their authority) recognised. It is in this refusal of authority that the Australian anxiety lies. The refusal in the passage à l'acte is manifested in a much less metaphorical way in Loizidou's discussions of the consequences of the Troika's economic austerity plans imposed on Greece. It is a physical suicide-the death of the subject-which, through its 
action, attempts to maintain dignity and in doing so also exposes the falseness of the fantasy that binds the sovereign and its subjects.

And then there is a third response to anxiety, which is passage à l'acte in its own right. That is not the anxiety of the subject, but the anxiety of the structure of the socio-political reality with modern liberal-democratic state as its derivative. The anxiety of the structure is the flip side of that of the subject. It is anxiety which recognises that the structure is also a fantasy. It exposes the incompleteness of the structure and the lacking signification, which bring the subject into a socio-political realm. The sovereign knows it is lacking, the law knows it is incomplete; it is then only a question of time when the subject discovers the lack or unconsciously provokes it into existence. The anxiety of the structure is well addressed in McDonald's contribution where the 'danger' of populism (of letting the people have too much power by opting for a choice) materialised in Brexit. A choice was presented to the people, but this was never to be an actual choice. By opting for Brexit, people sinned, they transgressed the law, and the law had to catch up with the sinners to alleviate the structural anxiety of their decision.

\section{Outline of the Special Issue}

This introduction is set out with two tasks in mind. The first task is (a) to ground the idea of anxiety in what can be considered a firmer theoretical and analytical framework and, in doing so, to demonstrate the importance of thinking conceptually about the role of anxiety in the modern socio-political realm; and (b) to offer a socio-political context for the five contributions in this special issue, and to stand in opposition to those discourses and arguments which mobilise anxiety because it is 'in fashion' (a fancy word substitute to fear or risk terminology) while failing to pay any attention to the existing history of the concept in political philosophy. In doing so, the introduction itself aims to make a (political) intervention. The second task is to provide a brief narrative about the five contributions the reader is offered here, to which now I turn.

This special issue offers five very much interrelated narratives about the political capital of anxiety and changes in the socio-political dynamics that the experience of anxiety triggers in either political subjects or in governing structures. While admittedly the introduction frames anxiety in a rather psychoanalytic Lacanian way, not all contributions adhere to that framework. What, nevertheless, they all have in common is the 'traumatic' experience and a set of events triggered by the emergence of anxiety.

As mentioned above, anxiety can be triggered by fear of transgression, the proximity of the 'desired object' or by the collapse of the symbolic order. It can be anxiety that entices action or one which draws subjects into passivity. It can be manifested in socio-political structures (such as the law, legislation, voting systems, referendums) or in political ideologies placed firmly on the left or on the right of the political spectrum or in-between. Considering the success of populist and racist fantasies, it then seems apt to open this special issue with Ari Hirvonen's contribution about the nationalist and racist politics of fantasy. Drawing on a 
number of examples from the most recent French presidential elections to Brexit, Hirvonen states that crises have become a new normality. Most recently the radical right seem also to have crossed that threshold of the normal. Hirvonen argues that the possibility of something once at the fringes turning into a normal/acceptable discourse lies in the intersection of fear and fantasy. It is fear of the outsiders that are somehow different from 'us' (the true Germans, true French or true Finns, as Hirvonen states) and which threatens our national unity, that is being mobilised. In Hirvonen's text, racism is considered in relation to, on the one hand, fear and anxiety and, on the other hand, the imaginary and symbolic orders and structures of fantasy. This analysis shows how xenophobic images, nationalist signifiers and racist fantasies create the vicious circles of fear and hate that give justification for the nationalist identity politics raising security as the hegemonic organising principle. To counter the nationalist identity politics, nationalist and racist fantasies must be traversed. Therefore, the possibility of anti-racist politics can only emerge if it departs from nationalist social fantasies based on pre-given identities. It takes place, as Hirvonen argues, only as an emancipatory event that confronts the racist and nationalist fantasy.

By contrast, Jaco Barnard-Naudé's piece explores what one can name a leftist fantasy of protest by examining the relationship between anxiety and hysteria. In Lacan's theory the discourse of the Hysteric can assume the position of the resisting subject - the subject who is committed to oppose any form of authority. By drawing on the most recent protests of students in South Africa, Barnard-Naudé proposes a different reading of Lacan's discourse of the Master (in this paper understood as liberal authority). He proposes to see it as a discourse that in its very structure exposes the (postcolonial) subject to the production of the object of anxiety. What in turn becomes crucial is how the postcolonial subject of post-Apartheid South Africa resolves its relation to anxiety. In this context Barnard-Naudé returns to the discourse of the Hysteric and looks at the way in which it is affected by anxiety. Depending on whether the action is performed as 'acting out' or as passage à l'acte, the subject can either derail its discourse or can reinforce it. While the derailment of the discourse is performed by the latter, the former (acting out) ends in the reinforcement of the discourse of the Hysteric. As Barnard-Naudé states, it is the acting out that prevails in South Africa, it is the desire to reinstate and invest (even if through negation and protest) oneself in the Master. Just as Lacan warned the students in 1968, the power of anxiety in South Africa continues to reproduce the same Master that the students oppose; not by chance but by students' active (unconscious) investment in the existing Master.

The intrigue in the relationship between the production of anxiety in the postcolonial environment continues in Juliet Rogers' contribution on the play of anxiety and the competing jurisdictions in post-colonial Australia. Rogers proposes to engage with the performance of anxiety particularly on the side of nonIndigenous Australians through the prism of Derridean justice. That is a type of justice that is never attainable; it is justice to come. Through a discussion of Freud and Lacan, Rogers interrogates what might be the cause of anxiety for nonIndigenous Australians and how that anxiety is played out on the bodies of Indigenous Australians. Resorting to humiliation and humiliating practices, which 
all remain within the realm of the legal and thus do not impose immediate sanctions, non-Indigenous Australians maintain an (un)conscious sense of superiority. Humiliation becomes a way of addressing their anxiety: that is, anxiety of the prospect that law has two names, that imagination cannot ever be secured in the symbolic world of law; that there might be more than one or even two masters. Or as Rogers concludes:

this anxiety must be managed, but never eradicated. Indigenous people are both the disruption to this management and the object $a$, which opens to its proximity. Humiliation is one form of management and enjoyment. It both keeps the subject alive and implicates it in the violence.

If Hirvonen explored anxiety through the right-wing fantasies of nationalism, Barnard-Naudé does so through leftist politics of resistance and Rogers through a proximity to the object $a$. Elena Loizidou's paper returns to one particular response to the experience of anxiety - that is, of suicide. As discussed earlier, the death of the subject or a suicide can represent a way of responding to anxiety. In as much as suicide narratives, on which Loizidou's paper draws, can represent a stark critique of the political reality or a plea for justice, they are also acts which can re-claim one's dignity. Since the financial crisis, as Loizidou argues, Greece saw a sustained increase in suicides; in 2011 of as much as $35.7 \%$. In such times suicide notes become a testimony to one's ultimate experience. Loizidou reads these notes as an account of critique of the anxious times. They offer a critique in two senses: a critique of the way we are being governed (through austerity memorandums and a neoliberal logic); and a critique of the affirmative ways of responding towards the financial crisis (through Occupations, demonstrations). Consequently these suicide notes can be read as a demand for having a break from the anxious neoliberal logic and organisation of life, and a call for a re-imagination of our social and political realm. Similarly to Hirvonen, Loizidou's paper calls for its own kind of 'anti-racist' politics.

Finally, with the last contribution we return to where we started-to the question of populism and anxieties over 'purity' of national identity. Angus McDonald sets his contribution entitled 'Our Democracy, Our Identity, Our Anxiety' in the theoretical framework of Kierkegaard and repeats his question about anxiety over a popular (populist) decision-making process-in the context of this paper, the referendum to leave the European Union (Brexit). The Brexit campaign revealed anxieties about national identity, immigration and sovereignty of the United Kingdom, whereas post-Brexit discussions lay open anxiety about the institution of the referendum and its legitimacy. With a reference to Kierkegaard's anxiety about democracy, McDonald draws on Lyotard's work and, on the one hand, discusses an appeal to mythic narrative to stabilise a claim of identity while, on the other hand, he interrogates the narratives of emancipation embodied in a future-oriented deliberative process which he analyses in terms of seven different types of language game at play. McDonald makes a particular reference to the image of 'triggering' used in the Supreme Court's judgments, in the Miller case ${ }^{3}$ in relation to Article 50

\footnotetext{
${ }^{3} R$ (on the application of Miller and another) $v$ Secretary of State for Exiting the European Union [2017] UKSC 5 .
} 
and the UK's exit from the EU, to illustrate the significance of figures of speech within discourse. In an attempt to stabilise the narrative about 'who we are' postBrexit referendum, as McDonald argues, political and legal mechanisms were triggered; yet, as it seems, no mechanism was able to do away with the persisting anxiety started by the Brexit populism. Despite a promise of a common identity of 'one sovereign people in control of our destiny', the populist narrative failed to provide a universally accepted mythic narrative about identity. Instead, the anxious abyss of 'who we are' persists.

Finally, what can be taken away from the contributions presented here; what is the political capital of the proposed understanding of anxiety; or how can anxiety reshape the socio-political landscape? When speaking of jouissance or object petit a or when addressing questions of resistance against the sovereign on the one hand, or the culmination of sovereign power in the voice of the people on the other hand, Lacan points to an element that these practices have in common-that is, knowledge. In his famous speech to the students at Vincennes during May 1968 Lacan voiced the words 'resist, but all you will get is a new master'. In doing so, Lacan was not pessimistic about the possibilities of resistance, political action or about imagining a different world. He might be cautious but not pessimistic about the voice of the people. However, he urged students to think about the path they chose to take, think of where their ideas will lead them, and warned them against being seduced by the act of resistance itself, and by the loud shouting of a refusal against that particular sovereign authority. In effect, he urged them to rethink the relationship between knowledge and jouissance (Lacan 1998). The contributions presented in this special issue all speak to this: in different ways they all show why one needs to be careful when mobilising anxieties; why it is easy to get seduced by the 'will of the people', by a narrative about a strong unified national identity, and by radical ideas emanating from the left or the right. The contributions, again in different ways, point to moments or ideas that have the capacity to break with the seductive narratives of the 'people': Hirvonen speaks about anti-racist politics; Barnard-Naudé about the traversal of the symbolic order (or passage à l'acte); Rogers about the struggle to attain the impossible justice and a refusal of recognition; Loizidou about suicide as the ultimate act which breaks with anxious politics, reclaims individual dignity and challenges the sovereign authority; and, finally, McDonald finds these moments in the agonistics of language games. Thus, when read together these contributions draw a map of the existing politics of anxiety, and illustrate what anxiety, when taken seriously, can do for the analysis of the socio-political terrain.

Acknowledgements The editors of this special issue would like to thank all the contributors for their provocative papers, engagements and prompt responses to comments and suggestions. It has been a real pleasure working with you. Thanks also to the Law \& Critique editorial team, to Valerie and Paddy in particular, for their efficiency and patience in the final few weeks.

Open Access This article is distributed under the terms of the Creative Commons Attribution 4.0 International License (http://creativecommons.org/licenses/by/4.0/), which permits unrestricted use, distribution, and reproduction in any medium, provided you give appropriate credit to the original author(s) and the source, provide a link to the Creative Commons license, and indicate if changes were made. 


\section{References}

Beck, Ulrich. 1992. Risk society: Towards a new modernity. London: SAGE Publications.

Bosteels, Bruno. 2006. Alan Badiou's theory of the subject: The recommencement of dialectical materialism. In Lacan: The silent partners, ed. Alain Badiou, 115-168. London: Verso.

Bourke, Joanna. 2006. Fear: A cultural history. Emeryville, CA: Shoemaker \& Hoard.

Eklundh, Emmy, Andrea Zevnik, and Emmanuel-Pierre Guittet. 2017. Introduction: The politics of anxiety. In The politics of anxiety, ed. E. Eklundh, A. Zevnik, and E.-P. Guittet, 1-15. London: Rowman and Littlefield International.

Freud, Sigmund. 1920. Fear and anxiety. In A general introduction to psychoanalysis. S. Freud. http:// www.bartleby.com/283/25.html. Accessed 1 August 2017.

Giddens, Anthony. 1991. The consequences of modernity. London: Polity Press.

Giddens, Anthony. 2013. Turbulent and mighty continental: What future for Europe?. London: Polity Press.

Kierkegaard, Søren. 2015. The concept of anxiety: A simple psychologically oriented deliberation. New York: Liveright.

Lacan, Jacques. 1977. L'impromptu de Vincennes. Le Magazine littéraire 121, février 1977.

Lacan, Jacques. 1998. The seminar of Jacques Lacan, Book XX: Encore. New York: W.W. Norton \& Company.

Lacan, Jacques. 2006. Ecrits: The first complete edition in English. New York: W.W. Norton \& Company.

Lacan, Jacques. 2007. The other side of psychoanalysis: The seminar of Jacques Lacan, Book XVII. London: W.W. Norton \& Company.

Lacan, Jacques. 2014. On anxiety: The seminar of Jacques Lacan, Book X. Cambridge: Polity Press.

Zevnik, Andreja. 2009. Sovereign-less subject and the possibility of resistance. Millennium: Journal of International Studies. 38(1): 83-106.

Zevnik, Andreja. 2017. Post-racial society as social fantasy: Black communities trapped between racism and a struggle for political recognition. Political Psychology 38(4): 621-635.

Žižek, Slavoj. 1992. Sublime object of ideology. London: Verso.

Žižek, Slavoj. 2005. Anxiety: Kierkegaard with Lacan. Lacanian Ink 26. http://www.lacan.com/ frameXXVI5.htm. Accessed: 1 August 2017. 